\title{
FEDERALISM AND CONSTITUTIONAL CHANGE IN NIGERIA
}

\section{Eyene Okpanachi* and Ali Garba**}

* Department of Political Science, University of Ibadan, Nigeria Email: eyeneokpanachi@yahoo.com

** Department of Political Science, University of Jos, Nigeria Email: accessgarba@yahoo.co.uk

\begin{abstract}
In comparison with established democracies Nigeria is a highly populated and ethnic fragmented state. Therefore after colonial rule and independence a federal constitutional structure was supposed to bring the processes for conflict resolution between the ethnic groups. In 1960 Nigeria started as a highly decentralised state and went through important changes until 1999 towards greater centralisation which found its culmination in regular military governments and open conflicts. Until 1999 each constitution promulgated by the military was considered as a step towards the transition to democracy. After the constitution making process, political actors aspired to constitutional reforms in a democratic way. Those attempts at mega constitutional change were not successful, which lead to military coups once again. This paper traces back mega-constitutional change in Nigeria between 1999 until 2007. After a brief introduction the paper proceeds with the foundations of federalism and constitution making in Nigeria. The following three paragraphs deal with the politics of constitutional change in Nigeria from 1999 until 2007. The final part of the paper compares the failure of Nigerian constitutional reforms with the case of Canada. As in the Canadian case, sub constitutional change in Nigeria is presented as a possible answer to demands of reform, instead of mega-constitutional reform.
\end{abstract}

Keywords: constitutional reform, Nigeria, federalism 


\section{About Federal Governance}

Federal Governance is an online graduate journal on theory and politics of federalism and multilevel governance. Its mandate is to engage the global federalism community and reach out to outstanding graduate students interested in federalism and multi-level governance. By providing a platform for graduate students to have early success in their careers, Federal Governance seeks to promote and sustain interest in federalism and multi-level governance research among graduate students. Allied with the Forum of Federations and founding partner, Institute of Intergovernmental Relations at Queen's University; Federal Governance aims to contribute to a global dialogue on federalism.

Co Chairs, Advisory Committee:

Publisher:

Managing Editor:

Associate Editors:

\section{Rupak Chattopadhyay and Christian Leuprecht}

Forum of Federations

(Rupak Chattopadhyay and Rod Macdonell)

Annegret Eppler

Joshua Cerovski, Dominic Heinz,

Eva-Maria Maggi and Victoria Tait

\section{Terms of Use}

Your use of this Federal Governance article indicates your acceptance of Federal Governance's Terms and Conditions of Use, available at www.federalgovernance.ca/terms. Federal Governance's Terms and Conditions of Use provides that you may use Federal Governance content only for personal, academic and non-commercial use. Each copy of any part of this Federal Governance article must contain the same copyright notice that appears on the screen or printed page of such transmission. 


\section{Introduction}

Nigeria has a population of over 140 million. Its diversity is enormous. There are over 374 ethno-lingual groups (Otitie 1990) each with its distinguishing culture and tradition. The political culture of Nigerians is highly influenced by their ethnic, religious and regional backgrounds and identities are constructed along similar lines.

Federalism became an inevitable choice for Nigerians at the terminal period of colonial rule as a result of Nigeria's diversity. It was adopted as a mechanism for managing conflicts that resulted from interactions among diverse groups in the country. Federalism remained a part of Nigeria's political system since independence in 1960 except for a brief period in 1966, when the military decreed a unitary system of government. Over the years, five constitutions were promulgated by military and civilian administrators. This resulted in significant changes in the federal structure, institutions and processes of Nigeria. The federation was transformed from a highly decentralized polity with three large component units at independence to a highly centralized one with 36 component units (states) and a Federal Capital Territory. There are also 774 local governments in the federation.

With the return to civilian rule in 1999, there have been complaints about the nature of the federal arrangement as it shapes interactions among groups and governments. Some of these complaints are attributed to constitutional flaws or inadequacies. Some groups have been agitating for a constitutional review to address these issues. A number of attempts were made in the past eight years. Unfortunately none of the attempts were successful. Another attempt is presently being made by the National Assembly. This paper provides a brief history of constitution making in Nigeria, highlights relevant issues considered for review and discusses the politics of constitutional change before drawing some prescriptive considerations.

\subsection{Federalism and constitution-making in Nigeria}

Federalism, according to Watts (1994: 7) is "not an abstract ideological model to which political society is to be brought into conformity, but rather a way or process of bringing people together through practical arrangements intended to meet both common and diverse preferences of people." This is essentially in line with Friedrich's (1964: 1) assertion that "federalism is a process rather than a design." It is "primarily the process of federalizing a political community" (Friedrich 1964: 7). That is to say, "the process by which a number of separate political communities enter into arrangements for working out solutions, adopting joint policies, and making joint decisions on joint problems, and conversely also the process by which a unitary political community becomes differentiated into federally engaged whole." Federalism is therefore generally seen as a technique, mechanism or practical method of solving practical problems. This explains why there is no ideal form or model of federal system. 
Two broad perspectives can be identified in conceptualizing federalism: the sociological and constitutional/legal perspectives (Brooks 1994: 136). On the one hand, the sociological viewpoint sees federalism as an institutionalized political cooperation and collective coexistence that emanates from the desire of a people to form a union without necessarily losing their identity. In essence, this perspective views federalism as a function of society - a product of the interaction of socio-cultural and political factors. Thus, the essence of federalism, argues Livingston (1956: 1-2), lies in the society and not the institutional or constitutional structure. On the other hand, the legal/constitutional viewpoint conceptualizes federalism as a form of governmental structure an institutionalized framework of power sharing that provides the framework for interaction among governments. It also protects rights of citizens and minorities. Federalism is therefore viewed as a property of the constitution (Brooks 1994: 136). Blindenbacher and Watts (2003: 12) noted, however, "Federal systems are a function of not only constitutions, but also of governments, and fundamentally of societies". The constitution thus becomes an essential requirement of federal governance such that it "can be symbolically important in fostering unity or discord within the country" (Anderson 2008: 55).

Since the terminal period of colonial rule Nigeria has adopted federal constitutions as a way of institutionalizing the principles of 'shared rule' and 'self-rule.' Significant changes in federal structure, institutions and processes were made but these basic principles have remained intact. However, the incursion of military into the political affairs of the country for nearly 30 years has negatively impacted the constitutionmaking process and therefore the various constitutions established. Of the five constitutions established since independence in 1960, three, including the present constitution, were promulgated by the military.

\subsection{Nigeria's constitution making history: from colonial to military rule}

Between the amalgamation of the Northern and Southern British Protectorates in 1914 and independence, four constitutions were established by different colonial administrations. These were the Clifford Constitution of 1922, Richards Constitution of 1946, Macpherson Constitution of 1951 and the Lyttleton Constitution of 1954. The 1954 Constitution laid the foundation for Nigerian federalism. From independence in 1960 to date Nigeria has been governed by five different constitutions. The Independence Constitution ushered in a new democratic government after almost five decades of colonial rule from 1914 to 1960. In 1963, the Republican Constitution was adopted to principally end political attachment to the England as a former British colony.

Having obtained formal independence in 1960, the nascent Nigerian state continued in its search for a reliable guideline that would reflect the aspiration of its newly independent people. Thus constitutional conferences were held both in London and Lagos as was the case in 1957 and 1958 respectively, for the purpose of ushering 
in the Independence Constitution of 1960. Unfortunately, instead of the Independence Constitution marking a total departure from the imposing Lyttleton Constitution, the constitution remained fundamentally colonial.

The political reality was that despite formal independence the Nigerian state was still being colonized by Britain, with the Queen of England serving as Nigeria's constitutional monarch and the final Court of Appeal for Nigeria remaining as the Judicial Committee of the British Privy Council. The situation implied that Nigeria was not really independent as being presented. Hence, despite the formal independence, Nigeria remained perpetually subservient to the political dictates of the colonial Lords in London.

Still struggling for viable rules and regulations to legally sustain the unconsolidated Nigerian polity, the leaders resolved that Nigeria should be a federal republic. Consequently, a constitutional conference was held in Lagos between July 25 and 26 , 1963. Thus provisions of the 1963 Republican Constitution removed the Queen of England as the Head of State of Nigeria. Similarly, the Supreme Court of Nigeria became the final Court of Appeal. On January 15, 1966, the military took over the government and consequently abolished the Republican Constitution. The First Republic after formal independence from 1960 lasted only six years and the military took over political power by force in 1966. The military ruled for thirteen years and handed over power in 1979. The Second Republic lasted only four years and the military took over again in 1983. The military ruled for another sixteen years and handed over power on May 29, 1999.

The 1979, 1989 and present 1999 Constitutions were advanced by the military as part of their transition to civilian rule. In between these constitutions, extraconstitutional laws and decrees were shaped and enforced by the military. The military also abolished the legislative arm of government and seized the function of lawmaking. Consequently, federal governance became an exclusive precept of the military through military 'legislative organs' (Elaigwu 2007: 103).

Superficially, the constitution-making process under the military was to be participatory especially as Constituent Assemblies (CAs) were inaugurated with members largely elected. Nevertheless, despite attempts at employing democratic procedures, the military's undemocratic temperament in the management of constitution-making processes in Nigeria's political history has affected the credibility of the process, and the perceived legitimacy of the constitutions. ${ }^{1}$ The precedent set in

For example, the 1999 Constitution of the Federal Republic of Nigeria was put together by a 25-member 'Constitution Debate Collating Committee' which was headed by Hon. Justice Niki Tobi of the Court of Appeal (as he then was). The Committee was set up by General Abdulsalam Abubakar regime in November 1998 solely to organise nationwide consultations on the 1995 draft Constitution. The Committee was given two months to complete its assignment, so it divided the country into zones, called for memoranda, organised debates, had special hearings and travelled to selected states, to listen to views from a wide range of groups. However, the Constitution of the Federal Republic of Nigeria (Promulgation) decree no. 24 of 1999 stated that the military leaders known as the Provisional Ruling Council 
colonial Nigeria has severely affected the present democratic government in the management of the constitution-making process.

\subsection{Constitution review in Nigeria's new democratic setting}

Since the return to democratic rule in 1999, the Nigerian political elites have made attempts to respond to the yearnings of groups and governments over the review of the constitution. On October 19, 1999 the former President, Olusegun Obasanjo set up a Presidential Technical Committee on the Review of the 1999 Constitution. The advisory committee worked for one year and five months, holding public sittings and examining submissions and memoranda before eventually turning in a report (1.) The report was presented at zonal centers between April 30 and May 29, 2000. The final report was then forwarded to the National Assembly for appropriate action. The National Assembly Joint Committee on Constitution Review (JCCR) set up in May 2000 failed to effect any change. The report of the committee was not transformed into a constitution because it was largely an advisory body. It was also alleged but never confirmed that the committee' effort were frustrated by some officials in or loyal to the Presidency who had another plan for the alteration of the constitution.

That alleged plan was to materialize in 2006 when the National Assembly JCCR under the leadership of the Deputy Senate President, Ibrahim Mantu recommended, among other amendments, the amendment of the Constitution to allow for the elongation of the tenure of the President and state governors beyond the constitutionally stipulated two consecutive terms of four years each. The proposed constitutional amendment was formally defeated on May 16, 2006 when the Senate voted against it, a decision that in effect undermined the other seemingly desirable clauses recommended for amendment. This dramatic decision by a National Assembly that was frequently referred to as the robber stamp of the president surprised many. However, as Joseph (2008) explained, more than formal rules, it was a combination of extensive civil society mobilization, "money politics" by administration foes, a timely media intervention, and Senator Nnamani's (the senate president's) courage that lay behind Nigeria's big no to the "big man."

Meanwhile, in 2005, the President Olusegun Obasanjo had convened a 400 member delegates' National Political Reform Conference (NPRC) charged with forging a national consensus on a new constitutional blueprint for 'reinforcing the unity, cohesion, stability, security, progress, development and performance of the Nigerian federation' (Obasanjo 2005: 72). After several months of deliberations, the NPRC ended in deadlock over demands by delegates from the Niger Delta, Nigeria's oilproducing region, for an increase in the derivation formula from the constitutionally stipulated $13 \%$ of "revenue accruing to the federation account directly from any natural

(PRC) made "such amendments as were deemed necessary in the public interest and for the purpose of promoting the security, welfare and good governance of the people of Nigeria". 
resources" to $25 \%$ in the short term and $50 \%$ in the long term. This position, " $25 \%$ derivation now and $50 \%$ ultimately", was vehemently rejected by the delegates from the non-oil producing states, especially the North. The argument of the delegates from the North was that acceding to this demand in an economy that solely depends on oil will lead to bankruptcy for the region and the entire federation. Ultimately, the $17 \%$ "compromise" reached was rejected by the Niger Delta delegates.

With the inauguration of a new civilian administration in 2007, another attempt was initiated by the National Assembly to review the 1999 Constitution by the National Assembly after the attempt that collapsed in 2006. Just like before, a Joint Committee of the National Assembly has been established to carry out this task. ${ }^{2}$ However, unlike the previous attempt, the committee's scope was narrowed. An agenda was set for the committee. Fifteen areas are to be considered for review. These issues include: making fundamental obligation of government binding and actionable; Scope of right of citizens; Autonomy of the legislature; uniformity and harmonization of tenure of chief executives of local, state and federal governments; Immunity of chief executives; subsistence of state electoral commissions; autonomy and independence of federal electoral commission- the Independent electoral Commission; Local government autonomy as a third tier of government; Local government joint account; devolution of powers; revenue sharing; election and related matters; right of exploration of mineral resources; true federalism; and state creation. ${ }^{3}$

\subsection{Politics of constitutional change in the Nigerian federation and the difficulty of mega constitutional change}

Nigeria, like many other federal countries, has a rigid constitution. Amending the constitution requires securing two-thirds majority in the two houses of the National Assembly. In addition, amendment requires approval by resolution of sub-national legislatures of not less than two-thirds of all the 36 states in the federation. This rigidity is sterner on issues that have to do with restructuring of the federation and fundamental rights of citizens. Amending the Constitution for these purposes or amending the Section that stipulates the procedure of altering the Constitution requires the approval of four-fifths majority of all the members of the National Assembly and approval of not less than two-thirds majority in all sub-national legislatures of federation. Securing

2 The National Assembly Joint Committee on the Review of the 1999 Constitution (JCCR), which was inaugurated late 2008 , is made up of 88 members, 44 from each of the chambers. In January 2009, the process of reviewing the 1999 Constitution by the National Assembly began on a sour note as the 44 members of the House of Representatives on the joint committee on the review of the 1999 Constitution staged a walk-out of the opening ceremony of a two-day retreat for the committee, over the controversy of who should be the chairman of the JCCR. The bone of the contention in the JCCR was over the designation for Deputy Speaker of the House in the committee. The Senate wants him to be 'vice-chairman' while the House members insist on him being 'co-chairman.'

3 This Day (Lagos) 2008, October 12, p.1-7. 
such majorities in the national and sub-national legislatures is quite a Herculean task given Nigeria's divisive politics of federalism. Compounding this is the fact that the politics of constitutional change in Nigeria vis-à-vis federalism is characterized by competition for control of power and state resources. It is centered on balancing (or capitalizing on) regional advantages. This difficulty is poignantly demonstrated in the politics of state creation.

Principally, structural imbalances in the Nigerian federation are viewed within the context of the colonial North and South. The structure of the federation at independence in 1960 comprised of 3 regions: two (later three) in the South and one in the North. The military fragmented the 4 big regions into 12 smaller states and equated the number of states between the North and South in 1967. The number has been unequal since 1976 when the military government increased the number of states from 12 to 19. Presently, the number of states in the geopolitical North is 19 while that in the South is 17 . There are clamors for additional states in virtually all the 36 states of the federation. In some cases, the number requested is more than one. It is to be noted that clamor for the creation of new states is motivated above all other factors by the centralized revenue allocation system and the automatic allocation of substantial revenues to states by a revenue formula that has to do more with equality of states and population rather than their revenue raising abilities (Suberu 2001). State creation therefore becomes largely an elite project to secure access to the "national cake."

However, the issue of creation of states is thorny in Nigeria's federal politics. Attempts to create new states are usually seen as tinkering with the precarious structural 'balance' in the federation. Thus, it is objected or countered with similar agitations from other regions. The scramble for more states can consume the whole constitutional review exercise in a way the tenure elongation issue ridiculed the 2006 attempt. Except in 1963 when the Midwest Region was created by a civilian government, all state creation exercises have been carried out by the military. Perhaps, this informed the frustration of a senator of the Federal Republic who recently declared that only the military can create new States. ${ }^{4}$ Another serving senator and member of the National Assembly Joint Committee on Constitutional Review (JCCR) expressed his fears. He laments:

"I don't see an easy ride on the issue of state creation in the proposed amendment [...] Nobody should have it that state creation can be easily achieved in Nigeria in a democratic dispensation." 5

These views are seen by many as those apologetic to the military. However, they point to the fact that Nigeria's constitution is rigid and hence difficult to amend. The rigidity of federal constitutions is a way of ensuring that fissiparous tendencies in the federalizing process are reduced. In Nigeria, the civil war experience after a loose

4 This frank public comment became a rallying point for the discourse on constitutional amendment. See Daily Sun (Lagos), 2009, January 10 for a perspective of the discourse.

5 Daily Sun (Lagos), ibid. 
federal arrangement before the first military coup in 1966 justifies the adoption of a rigid constitution that centralizes power. However, the present constitution was promulgated by the military. After nine years of democratic experience it is obvious that certain sections of the Constitution need to be amended. Yet there is no unanimity on how this constitutional reform should develop. Different perspectives have emerged on this.

First, some Nigerians question the legitimacy of the Constitution. The Constitution, it is argued, was promulgated by the military and hence it is undemocratic and illegitimate (Ihonbvere 2003: 203). Thus, any initiative of government arising from the same document is seen as a charade. The solution therefore is the convocation of a Sovereign National Conference (SNC). This conference, as its proponents argue, will give Nigerians unfettered opportunity to discuss how to shape their future in one geopolitical entity. It is a "safety valve or forum for groups to air their frustrations about perceived imperfections of the Nigerian federal system" (Dare 2003: 110). However, as Suberu (2005: 5) argued, the "SNC model originally evolved in the 1990s in Benin and other French-speaking African countries as a strategy for effecting the displacement of dictatorial regimes by diverse coalitions within civil society." Therefore the SNC is inappropriate for a country like Nigeria, where some formally democratic institutions already exist. Given the multilayered fluidity of ethnic boundaries in the country, proponents of the SNC have also failed to fashion generally acceptable guidelines for selecting delegates of ethnic groups and other groups to the conference. Finally, suggestions that the SNC would revisit the viability and modalities of Nigerian unity have often provoked suspicion and antipathy in a country where a million lives were lost in the 1967-70 civil war of national unity.

This position seemed to be upheld in 2005, when a coalition of opposition and groups under the aegis of Pro- National Conference Organization (PRONACO) organized what they called a Sovereign National Conference (SNC). The group had earlier rejected the government sponsored National Political Reforms Conference (NPRC) in its entirety for what they described as its lack of its popular support and sovereign powers, and consequently organized an alternative conference with sovereign powers, and with deliberations covering all issues without imposing no-go areas. Yet the PRONACO conference was characterized by the same deep divisions, controversies and stalemate that characterized the NPRC. In addition, the draft "People's Constitution" that finally emerged from this effort in 2006 has remained merely a draft yet to be transformed into any meaningful policy action.

The National Assembly therefore remains the most viable avenue through which the Constitution can be changed. Yet this option, as indicated earlier, remains very difficult especially on issues that have to do with federalism. 


\title{
5.1 Exploring other options: non-constitutional adaptations and incremental constitutional reform
}

Russell (1994: 8) x-rayed the Canadian constitutional crisis and concluded that megaconstitutional change is likely to be a very difficult process. This difficulty "will put pressure on informal methods of constitutional change and on devices for resolving constitutional disputes." His conclusions suggest the importance of informal and nonconstitutional adaptations, as well as the importance of judicial adjudications in the federalization process. His comment aligns with Suberu (2005: 6) who concluded after an examination of the proposals advocated by different ethnic and political groups in the country for "renovating the architecture of Nigeria's federalism" that:

\begin{abstract}
"short of a successful initiative by Nigeria's current leaders to mobilize national consensus behind positive constitutional change, or a democratic breakdown that would lead to a fresh round of constitutional review under military auspices, the country's best hope for political reform lies in working pragmatically but creatively through the current institutional framework to promote non-constitutional renewal."
\end{abstract}

1. Non-Constitutional Adaptations: As it has developed in the Canadian context, following two failed attempts during 1987-92 at mega-constitutional change, the idea of non-constitutional renewal assumes that a troubled federation 'has the capacity to adapt to changing needs and evolving circumstances regardless of the difficulty in implementing constitutional amendments' (Lazar 1998: 3-4; cf. Suberu 2005: 6). Elements of this "strategy of pragmatic, piecemeal, non-constitutional renewal" in the country since the restoration of civilian rule in 1999 include: Judicial Activism reflected in the "judiciary's work in trying to curb electoral malpractice" (Joseph 2008) and in "the bold, balanced, and broadly anti-centralist jurisprudence of the independent Supreme Court" in arbitrating a series of constitutional or federal-state disputes over revenue allocation, local government, anti-corruption legislation, urban planning, and party registration" (Suberu 2005: 7); the enactment of the Fiscal Responsibility Act in 2007 to enhance transparency and accountability in public finance; the establishment of the Nigeria Extractive Industries Transparency Initiative (NEITI)- Nigeria's subset of the global Extractive Industries Transparency Initiatives (EITI)- to increase transparency in the management of Nigeria's oil, gas and mining sectors; and the regulation of conflict in Nigeria's multi-ethnic federal system through the geopolitical zoning arrangement (whereby the 36 states of the federation are informally divided into 6 zones) for distribution of resources and the sharing of political power.

2. Incremental constitutional reform: Another approach worth pursuing is the issue of incremental constitutional reform. A crucial issue for such an enterprise is electoral reform. At the root of the governance problems that Nigeria faces today is the question of leadership. The leadership problem itself is fostered by the inability of the electoral system to give the citizens meaningful choices to elect their leaders under a free and fair environment. Elections in Nigeria have become a charade, what has been 
characterized as "voting without choosing" (Ake 1996). The products of this "choiceless democracies" (Mkandawire 1999: 119-135) are rulers who are neither representative of the people nor accountable to them. Confronted by this phenomenon, the potential of democracy for managing power struggles among the elites, enforce rules effectively and manage institutions/political process efficiently and transparently, let alone serve as an avenue through which the material deprivation of the people are redressed, is whittled down or completely eroded. Importantly, given the deficit in democratisation, not only has federal processes and politics failed to tap fully from the mutually reinforcing benefit and opportunities between federalism and democracy which scholars such as Wheare (1964) alluded to decades ago, but in some respect each of the concepts (federalism and democracy) has dragged down the other in ways that are mutually destructive. Electoral reforms are therefore imperative if the country must make any progress on federal governance.

Fortunately, there are steps in this direction. President Yar'Adua in a show of rare sincerity that is lacking in the political class in Nigeria wholeheartedly condemned the sham elections that brought him to power and undertook to set up an Electoral Reform Committee (ERC) that will make appropriate recommendations for the restoration of the sanctity of the ballot box. Consequently, the President in August 2007 announced the constitution of the ERC, which had, Justice Muhammed Lawal Uwais, retired Chief Justice of the Federation, as its chairman. The Committee submitted its report to the president in December 2008. The report contained far-reaching reforms such as denying the (partisan) Presidency control of the electoral commission and ensuring fair and timely resolution of disputes arising there from. To give concrete meaning to the reforms, the Committee recommended the passing of three bills. The first is the 1999 Constitution amendment bill. The second is Electoral Act 2006 amendment bill and the third is Electoral Offences Commission bill. As Festus Okoye, former Chairman of the Transition Monitoring Group (TMG) and a member of the ERC has noted, a pragmatic approach to escaping the constitutional amendment deadlock of the past is to concentrate on the electoral reform while leaving out the contentious issues of federalism which, if pursued, may likely end up rubbishing the whole exercise as it did in the past.

\section{Conclusion}

History shows that mega-constitutional politics only rarely succeed. This holds true as well for the reform of Nigerian federalism. Experience has shown that reform of constitutions and constitutional frameworks in deeply divided societies is no mean task. Lessons from failed constitutional settlements suggest that mega constitutional reforms with its inherent proclivity for expanding the agenda to include the demands of multiple groups, and opening the constitutional process to mass legitimisation through use of referenda can undermine political stability and the prospect of settlement. Canada's failed Charlottetown Accord (1992) poignantly reflected this. Nigeria's experience from 
1999 to 2007 has also buttressed this fact. But besides the "difficulties of attempting comprehensive rather than incremental constitutional restructuring where so many varied interests have to be reconciled at the same time in a process involving public participation" which contributed to Canada's "three decades of periodic federal crises" (Watts 1996: 353), the challenge for constitutional reform is more daunting for Nigeria because as indicated earlier, Nigerian political elites hardly take the right approach to issues that require constitutional review. Rather the process has been characterized by political intrigues, overriding personal ambitions, manipulations and elite and or 'big man' capture that have scuttled the whole exercises. There is no reason to suggest that this problem has changed. Thus as promising as non-constitutional adaptations and incremental constitutional changes (beginning with electoral reforms that could give meaningful choices to citizens to choose their leaders and hence enhance their capacity to actively participate in government decisions-making that affects their lives) are, there is no reason to suggest that these will be smooth sailing. Yet it is a road worth taking and it is more promising than mega-constitutional change. Besides, it would provide an ample ground for civil societies in the country to rise above section al and parochial interest to better advocate for reform. 


\section{References}

[1] Ake, C. 1996, Democracy and Development in Africa, Washington, DC: The Brookings Institution.

[2] Anderson, G. 2008, Federalism: An Introduction. Ontario: Oxford University Press.

[3] Blindenbacher, R. \& Watt, R. 2003, "Federalism in A Changing World: Conceptual Framework for the Conference" in Federalism in A Changing World: Learning From Each Other, eds. R. Blindenbacher \& A. Koller, Montreal: McGillQueens University Press.

[4] Brooks, D. 1993, Canadian Democracy: An Introduction. Toronto: McClellend Inc.

[5] Dare, L. 2003, "Federalist Deconcentration and Group Rights in Canada: Some Lessons for Nigeria" in Federalism in Africa: The Imperative of Democratic Change Vol. I., eds. A. Gana \& S. Egwu, Trenton: Africa World Press.

[6] Elaigwu, I. 2007, Politics of Federalism in Nigeria. London: Adonis and Abbey Publishers.

[7] Friedrich, C. 1964, "New Tendencies in Federal Theory and Practice." Paper presented at the $6^{\text {th }}$ World Conference of the International Political Science Association.

[8] Ihonbvere, J. 2003, "The Nigerian State as Obstacle to Federalism: Towards A New Constitutional Compact for Democratic Politics" in Federalism in Africa: The Imperative of Democratic Change Vol. II, eds. A. Gana \& S. Egwu, Trenton: Africa World Press.

[9] Joseph, R. 2008, "Progress and Retreat in Africa: Challenges of a "Frontier" Region", Journal of Democracy. vol. 19, no.2, pp. 94-108.

[10] Livingston, W. 1956, Federalism and Constitutional Change, Oxford: Clarendon Press.

[11] Mkandawire T. 1999, "Crisis management and the making of 'Choiceless Democracies"', in ed. R. Joseph, R., State, Conflict and Democracy in Africa, Boulder \& London: Lynne Rienner Publishers.

[12] Obasanjo, O. 2005, Dialogue Not To Dismember Nigeria, This Day (Lagos). February 23.

[13] Otite, O. 1990, Ethnic Pluralism and Ethnicity in Nigeria, Ibadan: Shaneson.

[14] Russell, P. 1994, "The Politics of Mega-Constitutional Change: Lessons for Canada" in Evaluating Federal Systems, ed. B. de Villiers, Dordrecht: Juta \& Co.

[15] Suberu, R. 2001, Federalism and Ethnic Conflict in Nigeria: Washington, D.C. United States Institute of Peace Press.

[16] Suberu, R. 2005, "Renovating the Architecture of Federalism in Nigeria: the option of non-Constitutional Renewal." Retrieved from www.northwestern.edu/african-studies/Pdfs/May2005Conference/suberu.pdf (access May 10, 2010). 
[17] Watts, R. 1996, "Canada: Three Decades of Periodic Federal Crises", International Political Science Review, vol. 17, no. 4, pp. 353-371.

[18] Watts, R.1994, "Contemporary Views on Federalism", in Evaluating Federal Systems, ed. B. de Villiers, Dordrecht: Juta \& Co.

[19] Wheare, K. C. 1964, Federal Government. London: Oxford University Press. 